Atmos. Chem. Phys., 13, 6023-6029, 2013

www.atmos-chem-phys.net/13/6023/2013/

doi:10.5194/acp-13-6023-2013

(C) Author(s) 2013. CC Attribution 3.0 License.

\title{
Airborne lidar measurements of surface ozone depletion over Arctic sea ice
}

\author{
J. A. Seabrook ${ }^{1}$, J. A. Whiteway ${ }^{1}$, L. H. Gray ${ }^{1}$, R. Staebler ${ }^{2}$, and A. Herber ${ }^{3}$ \\ ${ }^{1}$ Centre for Research in Earth and Space Science (CRESS), York University, 4700 Keele Street, Toronto, \\ Ontario, M3J 1P3, Canada \\ ${ }^{2}$ Environment Canada, 4905 Dufferin Street, Toronto, Ontario, M3H 5T4, Canada \\ ${ }^{3}$ Alfred Wegener Institute, Bussestrasse 24, 27570 Bremerhaven, Germany
}

Correspondence to: J. Whiteway (whiteway@yorku.ca)

Received: 31 October 2012 - Published in Atmos. Chem. Phys. Discuss.: 14 January 2013

Revised: 16 May 2013 - Accepted: 18 May 2013 - Published: 22 June 2013

\begin{abstract}
A differential absorption lidar (DIAL) for measurement of atmospheric ozone concentration was operated aboard the Polar 5 research aircraft in order to study the depletion of ozone over Arctic sea ice. The lidar measurements during a flight over the sea ice north of Barrow, Alaska, on 3 April 2011 found a surface boundary layer depletion of ozone over a range of $300 \mathrm{~km}$. The photochemical destruction of surface level ozone was strongest at the most northern point of the flight, and steadily decreased towards land. All the observed ozone-depleted air throughout the flight occurred within $300 \mathrm{~m}$ of the sea ice surface. A back-trajectory analysis of the air measured throughout the flight indicated that the ozone-depleted air originated from over the ice. Air at the surface that was not depleted in ozone had originated from over land. An investigation into the altitude history of the ozone-depleted air suggests a strong inverse correlation between measured ozone concentration and the amount of time the air directly interacted with the sea ice.
\end{abstract}

\section{Introduction}

It has been observed that ozone becomes depleted in air near the sea ice surface during the polar sunrise period in the Arctic (e.g., Oltmans, 1981; Oltmans and Komhyr, 1986; Bottenheim et al., 1986; Barrie et al., 1988, 1989; Seabrook et al., 2011) as well as the Antarctic (Jones et al., 2010). The observations find episodes when the ozone mixing ratio at the surface decreases from the normal 30-40 ppbv to near zero for periods ranging from hours to weeks at a time. The currently accepted mechanism (Simpson et al., 2007) for the destruction of tropospheric ozone involves bromine atoms originating from activation of inert sea salt bromide ions in fresh sea ice. Photochemical reactions convert the inert bromine into reactive $\mathrm{Br}$ atoms that deplete ozone in the boundary layer in a catalytic reaction cycle known as a bromine explosion (Wennberg, 1999). This is consistent with the detection of a strong inverse correlation between tropospheric ozone and filterable $\mathrm{Br}$ (Barrie et al., 1989) and the coincident detection of greater concentrations of $\mathrm{BrO}$ during ozone depletion events (Hausmann and Platt, 1994). The frequency and strength of these ozone depletions has implications for the overall mercury contamination of the snow/snowpack as the oxidation of gaseous elemental mercury (GEM) by $\mathrm{Br}$ and/or $\mathrm{BrO}$, leading to the production of total particulate mercury (TPM) and reactive gaseous mercury (RGM), is strongly correlated with ozone depletion events and the presence of reactive bromine (Lu et al., 2001; Steffen et al., 2008). McElroy et al. (1999) reported on measurements that indicated significant amounts of $\mathrm{BrO}$ and thus depleted ozone in the Arctic free troposphere. One of the aims of the study reported here was to determine whether there was evidence for ozone depletion in air above the surface layer that is not directly in contact with the sea ice surface.

In order to investigate spatial structure of Arctic surface ozone depletion events, a differential absorption, light detection and ranging instrument (differential absorption lidar, or DIAL) for the measurement of tropospheric ozone was operated from the Polar 5 research aircraft (Basler BT-67: rebuilt and modernized DC-3) as part of the PAMARCMIP 
2011 (Pan-Arctic Measurements and Arctic Regional climate model simulations) measurement campaign (Herber et al., 2012). Several flights out over the frozen Arctic Ocean were carried out from Barrow, Alaska, during April 2011. The observed structure of the surface ozone depletion events along the flight track provided a unique view that has been applied to assess the conditions in which the ozone depletion events occur.

\section{Measurement technique}

The basic method was to emit pulses of light into the atmosphere and record the backscatter signal as a function of time, or equivalently range. For a UV wavelength $\lambda$, absorbed significantly only by ozone, the backscatter signal is described as

$P(R, \lambda)=\frac{C}{R^{2}} \beta(R, \lambda) \exp \left[-2 \int_{0}^{R}[\sigma(\lambda) n(R)+\alpha(R, \lambda)]\right] \mathrm{d} R$,

where $P(R, \lambda)$ is the instantaneous received power from range $R$. The backscatter coefficient, $\beta(R, \lambda)$, represents the fraction of light scattered backward per unit length and per unit solid angle. The extinction coefficient, $\alpha(R, \lambda)$, is the fractional decrease in laser pulse intensity per unit length due to scattering and absorption by molecules and aerosols. The product of the ozone number density and absorption cross section, $\sigma(\lambda) n(R)$, is the fractional decrease in laser pulse energy per unit length due to absorption by ozone molecules. $C$ is a system constant that takes into account characteristics such as transmitted laser pulse energy, receiver aperture area, system optical throughput, and detector efficiency.

The lidar emitted multiple wavelengths in the UV that lie on the broad Hartley ozone absorption band $(266 \mathrm{~nm}$, $276 \mathrm{~nm}, 287 \mathrm{~nm}, 299 \mathrm{~nm})$. The differential absorption between wavelengths was employed to derive the ozone density. Ozone retrieval from the recorded signal was performed by calculating the slope of the logarithmic ratio of any pair of these signals as

$$
\begin{aligned}
& n(R)=\frac{-1}{2\left(\sigma\left(\lambda_{\text {on }}\right)-\sigma\left(\lambda_{\text {off }}\right)\right)} \\
& \left\{\frac{\mathrm{d}}{\mathrm{d} R}\left[\ln \left(\frac{P_{\text {on }}(R)}{P_{\text {off }}(R)}\right)\right]+2\left(\alpha_{\mathrm{m}}\left(R, \lambda_{\text {on }}\right)-\alpha_{\mathrm{m}}\left(R, \lambda_{\text {off }}\right)\right)\right\}
\end{aligned}
$$

where "on" denotes the wavelength with the larger ozone absorption cross section, and the term $2\left(\alpha_{\mathrm{m}}\left(R, \lambda_{\text {on }}\right)-\alpha_{\mathrm{m}}\left(R, \lambda_{\text {off }}\right)\right)$ is a correction factor to account for differential extinction due to molecular scattering. Ozone was derived using the temperature-dependent ozone absorption cross sections from the HITRAN 2008 database (Rothman et al., 2009).

For the measurements in this study, there was not a significant contribution to the signal by aerosol and cloud particles, and the differential absorption and scattering due to

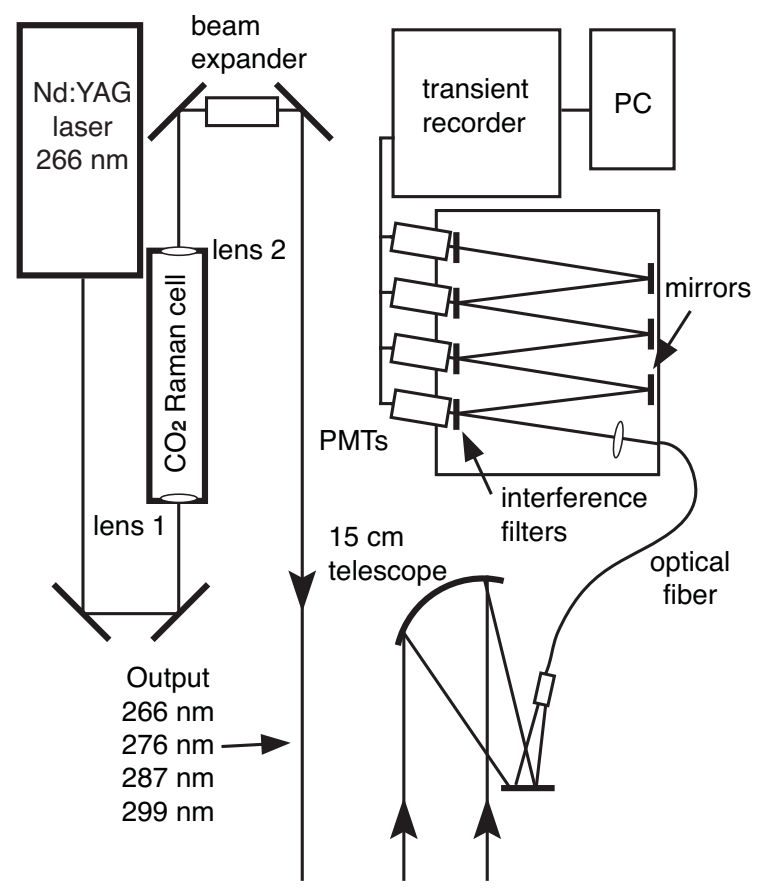

Fig. 1. Schematic diagram of the nadir viewing differential absorption lidar (DIAL).

aerosol had a negligible effect on the derived ozone concentration. Measurements where clouds were a significant factor were omitted from the analysis. The molecular scattering and extinction coefficients were calculated from atmospheric densities determined using data from meteorological radiosondes launched from Barrow, AK, MET station $\left(71.30^{\circ} \mathrm{N}, 156.78^{\circ} \mathrm{W}\right)$.

A schematic diagram of the DIAL system is shown in Fig. 1. The fourth harmonic of a Q-switched Nd:YAG laser $(266 \mathrm{~nm}, 70 \mathrm{~mJ}$ per pulse, $20 \mathrm{~Hz}$ repetition rate) is focused into the center of a cell filled with $140 \mathrm{PSI}$ of $\mathrm{CO}_{2}$ where stimulated Raman scattering into the first to third Stokes lines generates light with wavelengths of $276 \mathrm{~nm}, 287 \mathrm{~nm}$ and $299 \mathrm{~nm}$ (Nakazato et al., 2007). The diameter of the multiwavelength output beam was expanded by a factor of three to reduce the divergence to about $0.2 \mathrm{mrad}$ before it was directed into the atmosphere. Full overlap between the emitted laser pulse and the telescope field of view occurred at a range of $200 \mathrm{~m}$, and the signal received from within that range was not used in the ozone analysis.

Backscattered light was collected with a $15 \mathrm{~cm}$ diameter off-axis parabolic mirror and a $1.5 \mathrm{~mm}$ diameter optical fiber bundle positioned in the focal plane, $500 \mathrm{~mm}$ from the mirror, to form a receiver field of view of $3 \mathrm{mrad}$. The four wavelengths were separated in the receiver by the transmittance and reflectance from a series of tilted interference filters with bandwidths of $1 \mathrm{~nm}$. Photomultipliers were used to detect the optical signals and the data acquisition employed, both 


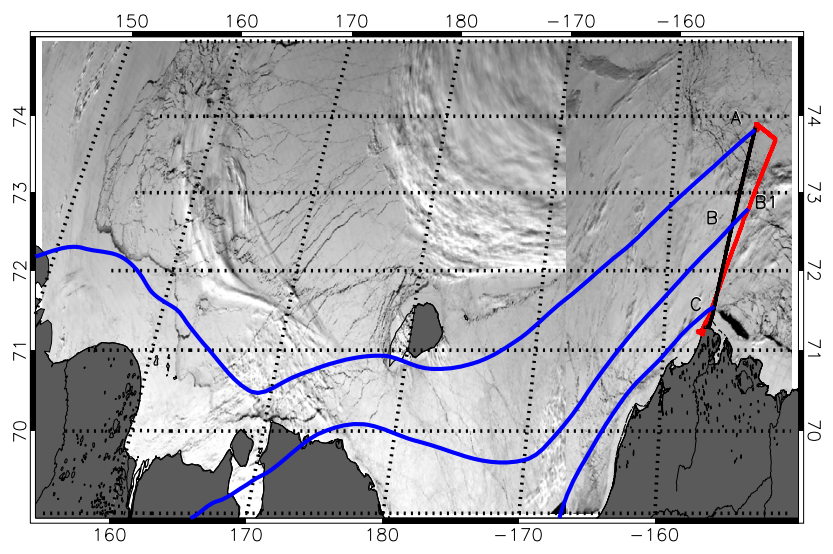

Fig. 2. Flight track of the Polar 5, out of Barrow, Alaska, overlaid on corresponding images from the MODIS instrument on the Terra satellite (Band 2, 841-876 nm). The black line indicates the portion of the inbound flight when the ozone DIAL was operational (3 April 00:45-02:15 UTC), red the outbound flight (2 April 21:503 April 00:45 UTC). The positions used for the case studies in the analysis (A, B, C, B1) are indicated along the flight path. Calculated air back trajectories at a height of $100 \mathrm{~m}$ (blue) are shown for the points $\mathrm{A}, \mathrm{B}$ and $\mathrm{C}$ and $\mathrm{B} 1$.

analog to digital conversion and photon counting in order to achieve linearity over a high dynamic range. The raw data were recorded with a range gate of $7.5 \mathrm{~m}$ and an integration period of 200 laser shots $(10 \mathrm{~s})$. The collected lidar profiles were averaged spatially and temporally in order to reduce the measurement uncertainty. The $266 / 287 \mathrm{~nm}$ analog signals were used to generate ozone profiles to a range of $2 \mathrm{~km}$. At greater ranges, photon-counting signals were used to determine ozone levels near the surface.

The DIAL was installed within a single aircraft rack $(56 \times 64 \times 130 \mathrm{~cm})$, which is a self-contained unit (apart from the laser power supply) with internal thermal control and vibration isolation. The laser and telescope view out through a window on the rack, which consists of two optical quality, UV anti-reflection coated glass plates, with argon gas filling the gap in order to avoid frosting. The rack is mounted to the seat rails with the window aligned above a port that is open to the atmosphere below the aircraft.

\section{Observations}

The DIAL system was operated during three flights over the sea ice north of Barrow, Alaska, between the dates of 30 March and 3 April 2011. Here we present measurements from a single flight taken on 2 April 2011, at 22:00 UTC, in which the Polar 5 aircraft departed Barrow for a flight track over the sea ice for a distance of $325 \mathrm{~km}$ to the northeast. Similar measurements were obtained during the other two flights. The outbound half of the flight, shown in red in
Fig. 2, was a low level flight at a height range $100-200 \mathrm{~m}$ above the sea ice. The DIAL measurements were carried out only during the return flight leg (black line in Fig. 2) while the aircraft was at a height of $2.2 \mathrm{~km}$. A contour plot of the DIAL ozone measurements along this flight track is shown in Fig. 3. The lidar return signals used in this contour were averaged temporally over a window of $200 \mathrm{~s}$, which corresponds to an average distance of approximately $12 \mathrm{~km}$ at the aircraft mean ground speed of $220 \mathrm{~km} \mathrm{~h}^{-1}$. Spatial averaging was also applied to the recorded signals such that the vertical resolution was $22.5 \mathrm{~m}$ for the analog and $75 \mathrm{~m}$ for the photon counting. At a flight altitude of $2200 \mathrm{~m}$, the typical backscatter return signal from the surface was a photon-counting rate of $30 \mathrm{MHz}$. This moderate signal strength did not cause any detector-signal-induced noise.

A persistent depletion of ozone was observed close to the surface throughout most of the flight. At the beginning of the measurement (indicated as case A in Fig. 3), approximately $300 \mathrm{~km}$ northeast of the nearest landmass, ozone mixing ratios of $10 \mathrm{ppbv}$ were observed at the surface, extending up to a height of $250 \mathrm{~m}$ above the sea ice. Above this altitude the mixing ratio started increasing with altitude until, at an altitude of $400 \mathrm{~m}$, background levels of approximately $40 \mathrm{ppbv}$ were observed. The general trend throughout this flight is that ozone concentration increased toward land while the vertical depth of the depletion also decreased. Within $20 \mathrm{~km}$ of the coast the surface ozone depletion is almost non-existent.

In situ ozone measurements were taken using a TE49C (Thermo Electron Inc., USA) with an air-sampling inlet located at the top of the aircraft. This provided a validation for the DIAL ozone measurements near the ice surface. The aircraft height on the outbound flight path was mostly within $100 \mathrm{~m}$ of the surface for sea ice thickness measurements, but at five locations there were ascents to heights ranging 150-200 $\mathrm{m}$ for instrument calibrations followed by immediate descent (Fig. 4). These ascents provided vertical profiles of in situ ozone measurements that can be compared with the DIAL measurements on the return flight leg. Figure 5 shows the ozone vertical profiles measured with the DIAL at three locations that will be used for case studies in the analysis. The location for the vertical profile of ozone measured by the DIAL in case B (Fig. 5b) corresponds to the position of an in situ vertical profile taken during the outbound portion of the flight (the position is labeled as case B1 in Fig. 4b) as determined by a backwards trajectory calculation. The DIAL and in situ vertical profile measurements are seen to be in agreement within the TECO accuracy of $\pm 1 \mathrm{ppb}$, and the DIAL measurement uncertainty of $\pm 3.5 \mathrm{ppb}$ at $150 \mathrm{~m}$ above the surface of the ice.

\section{Analysis}

Back-trajectory analysis of the air measured by the DIAL during the flight was performed with the NOAA HYSPLIT 


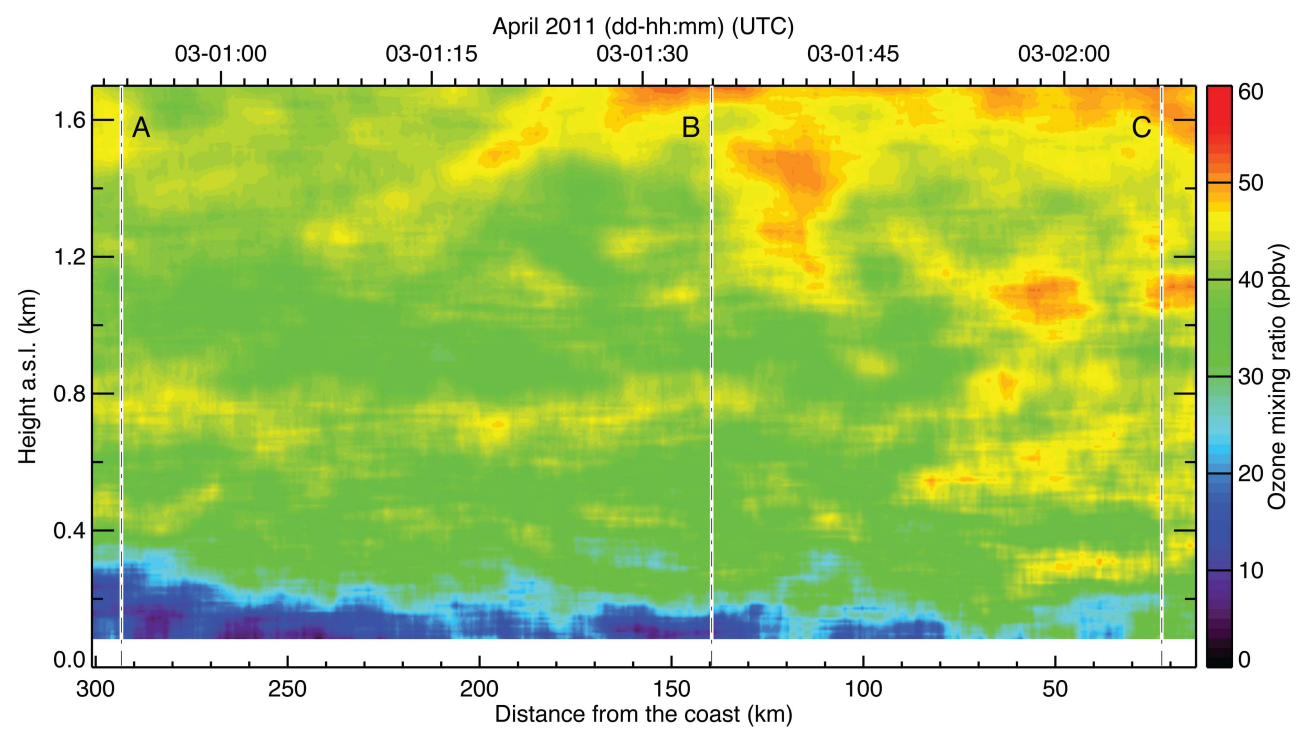

Fig. 3. DIAL measurements of ozone mixing ratio along the track of the aircraft shown in Fig. reffigure2. Lines labeled (A), (B) and (C) correspond to the positions of the aircraft labeled in Fig. 2, where the corresponding air back trajectories have been calculated.

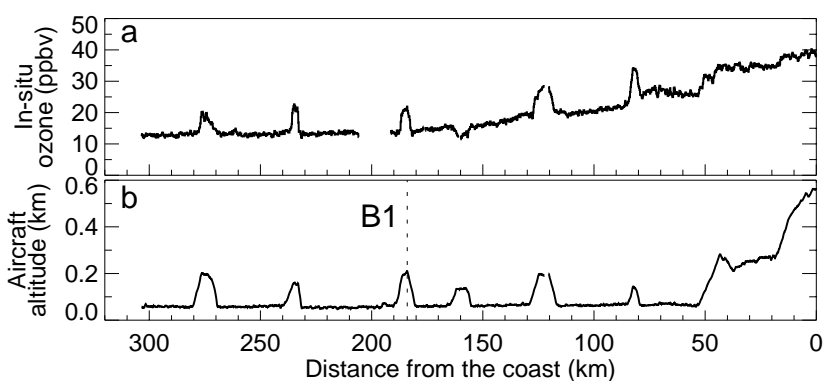

Fig. 4. (a) In situ ozone measurements along the outbound flight track (black trace in Fig. 2) with the distance from the coast of Alaska. (b) Aircraft altitude along the outbound flight track. B1 indicates the position of the aircraft during the outbound flight as labeled in Fig. 2.

model (Draxler and Hess., 1998), using GDAS (Global Data Assimilation System) meteorological data. The historical back trajectories were calculated every two minutes for the period of time in which the DIAL was active for heights ranging from $100 \mathrm{~m}$ to $2000 \mathrm{~m}$ a.s.l. and were calculated for a 6-day period backward starting from the GPS location of the aircraft at each time interval.

The period of time in which the strongest depletion was observed (case A) occurred at the northernmost extent of the flight track, approximately $300 \mathrm{~km}$ from the northern tip of Alaska (indicated as case A in Fig. 3). The ozone-mixing ratio was less than $10 \mathrm{ppbv}$ up to a height of $250 \mathrm{~m}$ and then increased to the background level of $30-40 \mathrm{ppbv}$ at a height of $400 \mathrm{~m}$. In this case the back trajectories shown in Fig. $6 \mathrm{a}$
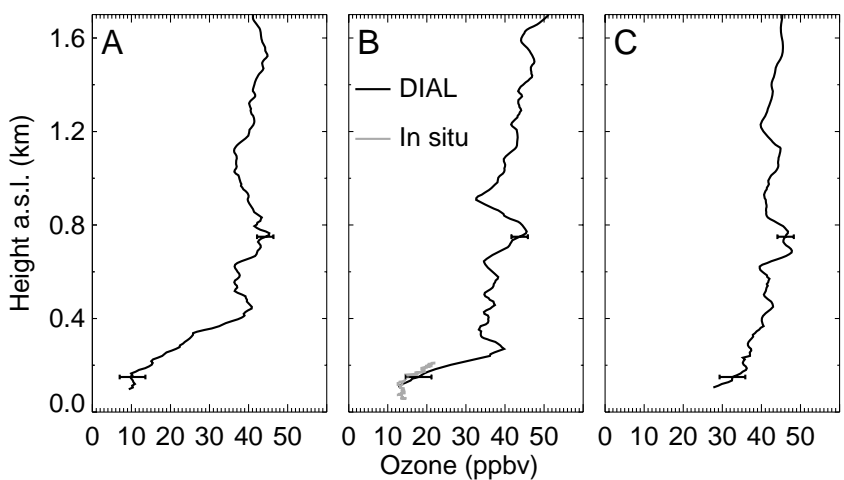

Fig. 5. Measured vertical profiles of ozone mixing ratio with the DIAL along the inbound flight track, and in situ measurements (gray line) along the outbound flight track (position B1 in Figs. 2 and $4 \mathrm{~b}$.). Cases (A), (B), and (C) correspond to the positions indicated in Figs. 2 and 3. The indicated uncertainty in the DIAL measurement is one standard deviation in the photon counts, propagated through the ozone derivation.

indicate that the air up to a height of $1000 \mathrm{~m}$ originated from the west over the Arctic sea ice. An analysis of the altitude history for case A (Fig. 7a) indicates that the air at $100 \mathrm{~m}$ and $300 \mathrm{~m}$ above the ice surface had spent significant time below $350 \mathrm{~m}$ in the previous days, while the back trajectories starting at heights of $500 \mathrm{~m}$ and $1000 \mathrm{~m}$ did not spend any time below $350 \mathrm{~m}$ in the previous six days.

In case B, approximately $140 \mathrm{~km}$ from land, the ozone depletion was observed to extend from the surface to a height 


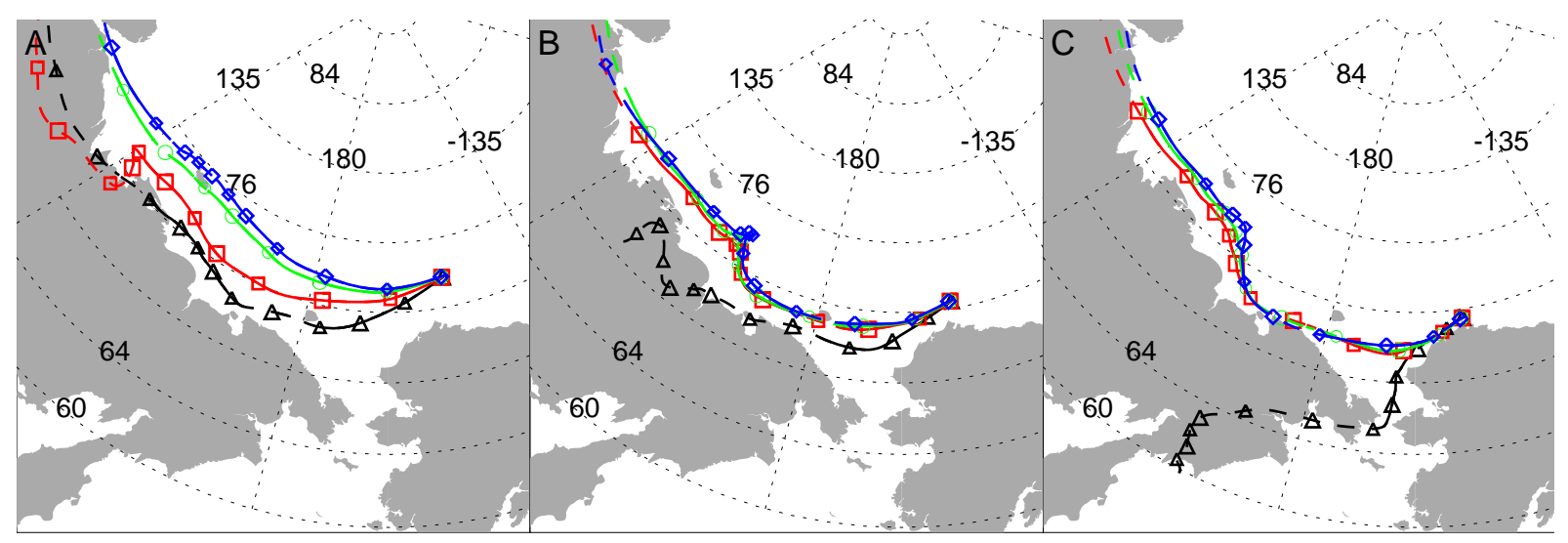

Fig. 6. Calculated back trajectories of air in which ozone was measured during the flight of 3 April 2011. The end point of the trajectories in A, B, and C correspond to the locations of the aircraft labeled in Figs. 2 and 3, and the cases in Fig. 5. Symbols indicate a period of $12 \mathrm{~h}$ has elapsed for the corresponding back trajectory. The trajectories are shown for air measured by the DIAL at heights of $100 \mathrm{~m}$ (black triangle), $300 \mathrm{~m}$ (red square), $500 \mathrm{~m}$ (green circle) and $1000 \mathrm{~m}$ (blue diamond).

of about $200 \mathrm{~m}$ (Figs. 3 and 5b). The depleted ozone concentration was not as low as observed in case A (Figs. 3 and 5a). Back-trajectory analysis (Fig. 6b) indicates that the origin of the measured air at an altitude of $100 \mathrm{~m}$ had shifted slightly to the south, such that the air closest to the surface spent more time over land than over the sea ice in comparison to case A. The altitude history (Fig. 7b) shows that air measured at a height of $300 \mathrm{~m}$ spent much less time below an altitude of $350 \mathrm{~m}$ in comparison to case A.

Near the end of the flight (case C), as the aircraft approached the coastline, the DIAL measured normal background levels of ozone (Figs. 3 and 5 c). There was no ozone depletion event at the coastline. Back-trajectory analysis indicates that the air at $100 \mathrm{~m}$ a.s.l., while spending the previous $60 \mathrm{~h}$ within the stable boundary layer, originated from the south and was not in contact with sea ice over the Arctic Ocean (Fig. 6c). The air measured at $300 \mathrm{~m}$ a.s.l. spent very little time within $300 \mathrm{~m}$ of the sea ice prior to being measured, and the air above $300 \mathrm{~m}$ spent no time within $300 \mathrm{~m}$ of the sea ice during the six days prior to being measured near Barrow, AK (Fig. 7c).

Open leads and first year ice have been considered to be an important source of the bromine that causes surface level ozone depletion (Piot and Glasow, 2008). A comparison of calculated back trajectories to images from the MODIS instrument on the Terra satellite (Fig. 2) indicated that, for case A, the air measured at an altitude of $100 \mathrm{~m}$ travelled over an area with a significant amount of open water or recently frozen-over leads. The leads are seen in the East Siberian Sea as dark jagged features in the MODIS image (latitude $150^{\circ} \mathrm{E}-180^{\circ} \mathrm{E}$ ). MODIS imagery taken a few hours before the flight (2 April, 21:25 UTC) shows a number of open or recently frozen-over leads near the northern segment of the flight path. Measurements of sea ice thickness by a tethered
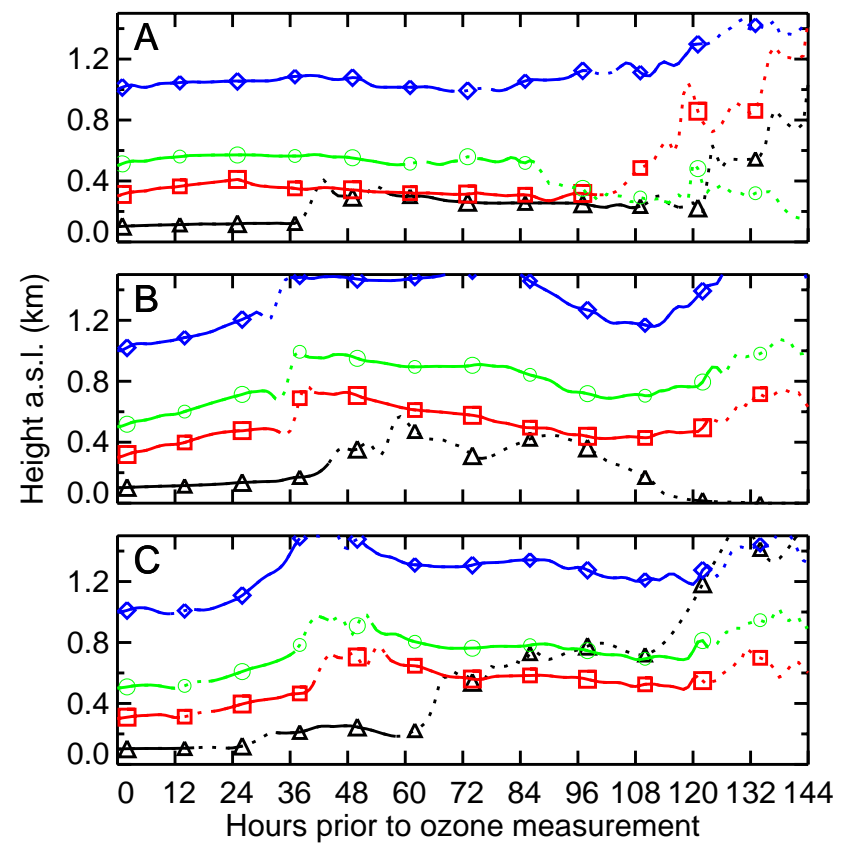

Fig. 7. Altitude history of the calculated back trajectories at heights of $100 \mathrm{~m}$ (black triangle), $300 \mathrm{~m}$ (red square), $500 \mathrm{~m}$ (green circle) and $1000 \mathrm{~m}$ (blue diamond). The end point of the trajectories in $\mathrm{A}, \mathrm{B}$, and $\mathrm{C}$ correspond to the location of the aircraft indicated in Figs. 2 and 3 and the cases in Fig. 5. Solid lines indicate that the air is over ice, and dotted lines indicate land. Coloured symbols on each trajectory correspond to those in Fig. 6. 


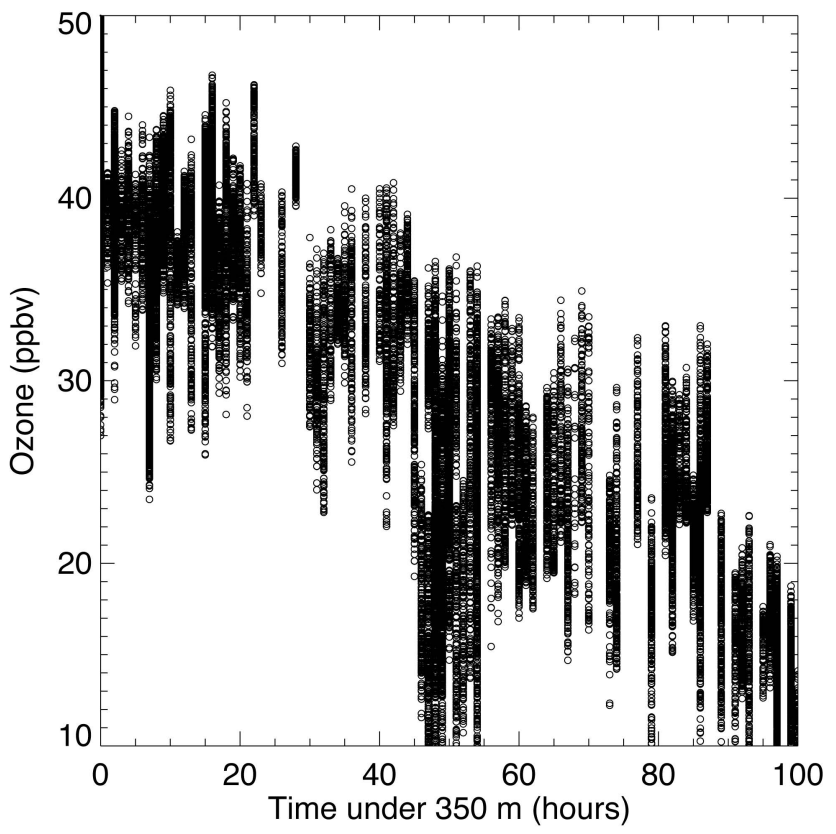

Fig. 8. Measured ozone concentrations vs. time the measured air spent at heights below $350 \mathrm{~m}$ over the sea ice during the six days prior to being measured.

EM induction instrument (e.g., Haas et al., 2010) during the outbound segment of the flight (red flight path in Fig. 2) indicated approximately $20 \%$ open or newly frozen water.

This case study, involving a single $300 \mathrm{~km}$ flight over the sea ice north of Barrow, AK, indicates that in this instance there was a correspondence between the ozone concentrations over the sea ice and the history of the air. By calculating the amount of time a back trajectory spent within $350 \mathrm{~m}$ of the sea ice over the previous few days, and comparing that with the measured ozone value, it was found that lower ozone mixing ratios were associated with air that had spent a longer amount of time in close proximity with the sea ice (Fig. 8). The general trend during this flight was that longer periods of time near the sea ice were associated with lower measured ozone mixing ratios.

\section{Conclusions}

The airborne DIAL measurements from the flight beginning on 2 April 2011 provided a continuous record of the vertical structure of a surface ozone depletion event over a horizontal range of $300 \mathrm{~km}$. At a distance of $300 \mathrm{~km}$ from the Alaska coastline, the layer of air adjacent to the sea ice was depleted in ozone up to a height of 300-400 $\mathrm{m}$ above the surface. Analysis of the prior trajectory of the measured air indicated that the ozone-depleted air had spent extended periods of time within $350 \mathrm{~m}$ of sea ice. Close to the coastline the air was not depleted in ozone, and the corresponding backtrajectory analysis indicated that this air had spent significant time over land, or did not have a history of being within the surface layer over the sea ice. The observed layer of ozonedepleted air was limited in vertical extent to the surface boundary layer and was always in contact with the surface of the Arctic Ocean. There was no evidence of isolated layers of ozone-depleted air above the surface boundary layer. The measurements thus indicate that the primary mechanism for the ozone depletion occurred within the surface boundary layer where turbulent mixing would result in contact with the frozen ocean surface. Images from the MODIS instrument on the Terra satellite over the area upwind from the flight path show the presence of leads in the ice with open or recently frozen water, and these are a possible source of the bromine required for the photochemical depletion of ozone.

The measurements presented here are limited to a single flight path with a length of $300 \mathrm{~km}$ and thus correspond to a small period of time. The measurements on the two other flights found a similar structure of surface layer ozone depletion events. The results are consistent with the findings of a previous study in which the same DIAL instrument provided measurements of ozone from the surface on board the CCGS Amundsen icebreaker ship during the entire month of March 2008 (Seabrook et al., 2011). This is also consistent with previous studies using back-trajectory analysis (Bottenheim et al., 2009; Frieß et al., 2004) that have found a correlation between Arctic ozone depletion events and the length of time prior to being sampled that an air mass was within the surface layer over the sea ice.

Acknowledgements. Christian Haas of York University provided the estimate of the fraction of open or recently refrozen leads in the sea ice below the aircraft flight path, based on sea ice thickness measurements. Support for the installation and operation of the lidar was provided by the International Polar Year program of the Natural Sciences and Engineering Research Council (NSERC) of Canada. Support for the analysis of the measurements was provided by the NSERC Discovery program. The satellite data used in this study were acquired as part of NASA's Earth-Sun System Division and archived and distributed by the MODIS Adaptive Processing System (MODAPS).

Edited by: J. W. Bottenheim 


\section{References}

Barrie, L., Bottenheim, J., Schnell, R., Crutzen, P., and Rasmussen, R.: Ozone destruction and photochemical reactions at polar sunrise in the lower Arctic atmosphere, Nature, 334, 138-141, doi:10.1038/334138a0, 1988.

Barrie, L., Hartog, G., Bottenheim, J., and Landsberger, S.: Anthropogenic aerosols and gases in the lower troposphere at Alert Canada in April 1986, J. Atmos. Chem., 9, 101-127, doi:10.1007/BF00052827, 1989.

Bottenheim, J., Gallant, A., and Brice, K.: Measurements of $\mathrm{NO}_{Y}$ species and $\mathrm{O}_{3}$ at $82^{\circ} \mathrm{N}$ latitude, Geophys. Res. Lett., 13, 113116, doi:10.1029/GL013i002p00113, 1986.

Bottenheim, J., Netcheva, S., Morin, S., and Nghiem, S.: Ozone in the boundary layer air over the Arctic Ocean: measurements during the TARA transpolar drift 2006-2008, Atmos. Chem. Phys., 9, 4545-4557, doi:10.5194/acp-9-4545-2009, 2009.

Draxler, R., and Hess, G.: An overview of the HYSPLIT 4 modelling system for trajectories, dispersion, and deposition, Aust. Meteorol. Mag., 47, 295-308, 1998.

Frieß, U., Hollwedel, J., Konig-Langlo, G., Wagner, T., and Platt, U.: Dynamics and chemistry of tropospheric bromine explosion events in the Antarctic coastal region, J. Geophys. Res., 109, D06305, doi:10.1029/2003JD004133, 2004.

Haas, C., Hendricks, S., Eicken, H., and Herber, A.: Synoptic airborne thickness surveys reveal state of Arctic sea ice cover, Geophys. Res. Lett., 37, doi:10.1029/2010GL042652, 2010.

Hausmann, M., and Platt, U.: Spectroscopic measurement of bromine oxide and ozone in the high Arctic during Polar Sunrise Experiment 1992, J. Geophys. Res., 99, 25399-25413, doi:10.1029/94JD01314, 1994.

Herber, A. B., Hass, C., Stone, R. S., Bottenheim, J. W., Liu, P., Li, S.-M., Staebler, R. M., Strapp, J. W., and Dethloff, K.: Regular airborne surveys of Arctic sea ice and atmosphere, Eos Trans. AGU, 93, 41, doi:10.1029/2012EO040001, 2012.

Jones, A., Anderson, P., Wolff, E., Roscoe, H., Marshall, G., Richter, A., Brough, N., and Colwell, S.: Vertical structure of Antarctic tropospheric ozone depletion events: characteristics and broader implications, Atmos. Chem. Phys., 10, 7775-7794, doi:10.5194/acp-10-7775-2010, 2010.

Lu, J. Y., Schroeder, W. H., Barrie, L. A., Steffen, A., Welch, H. E., Martin, K., Lockhart, L., Hunt, R. V., Boila, G., and Richter, A.: Magnification of atmospheric mercury deposition to polar regions in springtime: The link to tropospheric ozone depletion chemistry, Geophys. Res. Lett., 28, 3219-3222, doi:10.1029/2000GL012603, 2001.
McElroy, C. T., McLinden, C. A., and McConnell, J. C.: Evidence for bromine monoxide in the free troposphere during the Arctic polar sunrise, Nature, 397, 338-341, doi:10.1038/16904, 1999.

Nakazato, M., Nagai, T., Sakai, T., and Hirose, Y.: Tropospheric ozone differential-absorption lidar using stimulated Raman scattering in carbon dioxide, Appl. Optics, 46, 2269-2279, doi:10.1364/AO.46.002269, 2007.

Oltmans, S.: Surface ozone measurements in clean air, J. Geophys. Res., 86, 1174-1180, doi:10.1029/JC086iC02p01174, 1981.

Oltmans, S., and Komhyr, W.: Surface ozone distributions and variations from 1973-1984 measurements at the NOAA geophysical monitoring for climatic change baseline observatories, J. Geophys. Res., 91, 5229-5236, doi:10.1029/JD091iD04p05229, 1986.

Piot, M., and von Glasow, R.: The potential importance of frost flowers, recycling on snow, and open leads for ozone depletion events, Atmos. Chem. Phys., 8, 2437-2467, doi:10.5194/acp-82437-2008, 2008.

Rothman, L., Gordon, I., and Barbe, A.: The HITRAN 2008 molecular spectroscopic database, J. Quant. Spectrosc. Ra., 110, 533572, doi:10.1016/j. jqsrt.2009.02.013, 2009.

Seabrook, J. A., Whiteway, J., Staebler, R. M., Bottenheim, J. W., Komguem, L., Gray, L. H., Barber, D., and Asplin, M.: LIDAR measurements of Arctic boundary layer ozone depletion events over the frozen Arctic Ocean, J. Geophys. Res., 116, doi:10.1029/2011JD016335, 2011.

Simpson, W. R., et al.: Halogens and their role in polar boundary layer ozone depletion, Atmos. Chem. Phys., 7, 4375-4418, doi:10.5194/acp-7-4375-2007, 2007.

Steffen, A., Douglas, T., Amyot, M., Ariya, P., Aspmo, K., Berg, T., Bottenheim, J., Brooks, S., Cobbett, F., Dastoor, A., Dommergue, A., Ebinghaus, R., Ferrari, C., Gardfeldt, K., Goodsite, M. E., Lean, D., Poulain, A. J., Scherz, C., Skov, H., Sommar, J., and Temme, C.: A synthesis of atmospheric mercury depletion event chemistry in the atmosphere and snow, Atmos. Chem. Phys., 8, 1445-1482, doi:10.5194/acp-8-1445-2008, 2008.

Wennberg, P.: Atmospheric chemistry: Bromine explosion, Nature, 397, 299-301, doi:10.1038/16805, 1999. 